\title{
In vitro antifungal potential of surfactin isolated from rhizospheric Bacil- lus thuringiensis Berliner 1915 against maize (Zea mays L.) fungal phy- topathogen Fusarium graminearum Schwabe
}

\author{
Muddasir KHAN ${ }^{1,2}$, Muhammad SALMAN ${ }^{1}$, Abdullah ${ }^{1}$, Syed Hussain SHAH ${ }^{1}$; Muhammad ISRAR ${ }^{3}$
}

Received September 16, 2021; accepted November 29, 2021. Delo je prispelo 16. septembra 2021, sprejeto 29. november 2021

In vitro antifungal potential of surfactin isolated from rhizospheric Bacillus thuringiensis Berliner 1915 against maize (Zea mays L.) fungal phytopathogen Fusarium graminearum Schwabe

Abstract: Fusarium graminearum fungus cause significant loss in maize (Zea mays L.) and other cereal crops all over the world. The usage of chemical agents cause severe environmental problems. Bacillus species and other plant growthpromoting bacteria (PGPR) play key role in biopesticide development. A wide range of environmentally safe antimicrobial agents are already being manufactured. The current investigation was focused on exploring the antifungal activity of Bacillus thuringiensis lipopeptide surfactin against fungal phytopathogen Fusarium graminearum. B. thuringensis was isolated from the rhizosphere of maize crop and cultivated to produce lipopeptides. Surfactin was identified by high-performance liquid chromatography (HPLC) from the extract at $210 \mathrm{~nm}$, retention time 3-5 minutes and the obtained peaks area was 3.990. The growth of F. graminearum was successfully inhibited by surfactin at different concentrations. Among these, $80 \%$ concentration showed the highest zone of inhibition in comparison to $60 \%, 40 \%$ and $20 \%$ concentrations ( $p<0.005)$, respectively. The current study concludes $B$. thuringensis lipopeptide surfactin has a high potential to inhibit the growth of F. graminearum.

Key words: surfactin; Bacillus; biological control; HPLC; Fusarium graminearum
In vitro protiglivni potencial surfaktina, izoliranega iz bakterije Bacillus thuringiensis Berliner 1915 iz rizosfere koruze (Zea mays L.) proti patogeni glivi Fusarium graminearum Schwabe

Izvleček: Gliva Fusarium graminearum povzroča znantne izgube v pridelku koruze in drugih žit širom po svetu. Uporaba kemičnih sredstev za zatiranje povzroča resne okoljske probleme. Vrste iz rodu Bacillus in druge rast vzpodbujajoče bakterije (PGPR) igrajo ključno vlogo pri razvoju biopesticidov. Proizveden je bil že širok spekter okolju prijaznih antimikrobnih agensov. Raziskava se osredotoča na uporabo protiglivne aktivnosti lipopeptidnih surfaktinov iz bakterije Bacillus thuringiensis proti patogeni glivi Fusarium graminearum. Bakterija B. thuringensis je bila izolirana iz rizosfere posevka koruze in gojena za proizvodno lipopeptidov. Surfaktin je bil določen s tekočinsko kromatografijo visoke ločljivosti (HPLC) iz izvlečka pri 210 nm, retencijskim časom 3-5 minut, dobljeni višek je bil 3.990. Rast patogene glive je bila uspešno zavrta pri različnih koncentracijah surfaktina. $80 \%$ koncentracija surfaktina je pokazala največjo sposobnost zaviranja $\mathrm{v}$ primerjavi s koncentracijami $60 \%, 40 \%$ in $20 \%(p<0,005)$. Na osnovi te raziskave lahko zaključimo, da ima lipopeptidni surfaktin iz bakterije $B$. thuringensis velik potencial za zaviranje rasti glive F. graminearum.

Ključne besede: surfaktin; Bacillus; biološka kontrola; HPLC; Fusarium graminearum

1 Department of Health and Biological Sciences, Abasyn University Peshawar, Khyber Pakhtunkhwa, Pakistan

2 Corresponding author, e-mail: mk03025678947@gmail.com, muddasir.khan0302@gmail.com

3 Department of Microbiology, Abbottabad University of Science and Technology, Khyber Pakhtunkhwa, Pakistan 


\section{INTRODUCTION}

Globally Bacillus thurenginisis is considered to be the most predominant soil-dwelling bacterium found in the plants rhizosphere known for their antimicrobial properties. Aforementioned, Bacillus strains are known as plant growth promoting rhizobacteria (PGPR) that are associated with plants tolerance against biotic, and abiotic stresses caused by certain fungal phytopathogens (Saxena et al., 2019). In this context the worldwide major loss of maize and other cereal crops is due to fungal phytopathogens. The repertoire of fungal phytopathogens in cluding Acremonium alternatum Link ( $\mathrm{Pal}$ and Gardener, 2006), Ustilago maydis (DC.) Corda ${ }^{\text {( }}$ (Kwon et al., 2021), Aspergillus niger van Tieghem, Aspergillus flavus Link, Puccinia sorghi Schwein., Fusarium species (Rehman et al., 2021), Helminthosporium, Alternaria, Rhizopus, Penicillium, Drechslera (Snetselaar and McCann, 2017), Macrophomina phaseolina (Tassi) Goid., and Colletotrichum graminicola D.J. Politis (Saleem et al., 2012), cause varieties of disease in maize.

Maize (Zea mays L.) is the most important cereal crop in the world, covering $75 \%$ of the food requirements all over the world (Hussain et al., 2013). In Pakistan, among the cereal crops, maize is the third most important crop, after wheat and rice. Among these, globally the most important and significant phytopathogen is Fusarium graminearum, which causes significant loss of grain crops (Rauwane et al., 2020). The wide range of diseases caused by this plant pathogen includes; fruit rots, Fusarium head blight (FHB), wilts, and root rots (Kant et al., 2011).

Chemical compounds have been used to manage these fungal phytopathogens for many decades. They have a potential to generate major environmental problems. Alternative and less environmentally detrimental measures are required to control these plant diseases. Bacillus species and other PGPR play a key role among biopesticides. They produce various antimicrobial compounds such as enzymes, lipopeptides, and antibiotics that stimulate plant development while inhibiting pathogenic microbes (Shafi et al., 2017). For B. thurenginisis cyclic peptides including, surfactin, mycobacillin, mycosubtilin, subtilin, bacilysin, fengycin, bacillomycin, and iturin are reported that exhibit both antibacterial, and antifungal properties (Khan et al., 2021; Ntushelo et al., 2019).

Surfactin is a lipopeptide composed of cyclic depsipeptides of $\beta$-hydoxy hepta with possible amino acid combinations of alanine, valine, leucine, or isoleucine at positions 2, 4, and 7 in the cyclic depsipeptide moiety and $\beta$-hydoxy fatty acid chain variants of $\mathrm{C}_{13}$ to $\mathrm{C}_{16}$ in the cyclic depsipeptide moiety and $\beta$-hydoxy fatty acid chain variant (Hue et al., 2001). According to the investigations surfactin has natural antifungal properties produced by Bacillus spp. that could inhibit the growth of certain fungal species including, F. graminearum (Khan et al., 2021), Fusarium oxysporum Schlecht. emend. Snyder \& Hansen (Kim et al., 2010), Colletotrichum gloeosporiodes (Penz.) Penz. \& Sacc. (Snook et al., 2009), Fusarium verticillioides (Sacc.) Nirenberg (Dunlap et al., 2011), and Fusarium moniliforme (Sacc.) Nirenberg (Vitullo et al., 2012).

Therefore, the current study was designed to isolate and characterize $B$. thuringiensis lipopeptide from rhizospheric soil and also to assess its antifungal efficacy against the fungal phytopathogen F. graminearum of maize.

\section{MATERIALS AND METHODS}

\subsection{BACTERIAL AND FUNGAL ISOLATION}

A total of 20 maize rhizospheric soil samples were collected from various locations in Peshawar, Pakistan, for the isolation of B. thuringiensis (Figure 1). B. thuringiensis was identified using colony morphology, gram staining, and biochemical-tests such as citrate hydrolysis, catalase, indole production, nitrate reduction, Voges-Proskauer (VP), motility, $\mathrm{H}_{2} \mathrm{~S}$ production, and crystal formation (Amin et al., 2015). F. graminearum was isolated using a sample acquired from a diseased maize plant in Peshawar, Pakistan (Figure 1), and identified using colony morphology and microscopic analysis (Uddin et al., 2019; John et al., 2006).

\subsection{LIPOPEPTIDE EXTRACTION AND IDENTIFI- CATION}

In a shaking flask containing nutrient broth medium $\left(\right.$ Oxoid $\left.^{\mathrm{m}}\right)$, all morphological and biochemical based confirmed isolated colonies of $B$. thuringiensis were injected. The flask was incubated for 16 hours at $30^{\circ} \mathrm{C}$ with shaking incubator at $200 \mathrm{rpm}$. Afterward the culture was transferred to an Erlenmeyer flask containing $99 \mathrm{ml}$ of Tryptic Soy Broth (TSB) medium (Oxoid ${ }^{\mathrm{Tm}}$ ) and incubated overnight at $30^{\circ} \mathrm{C}$ with shaking incubator at $200 \mathrm{rpm}$. The optical density (OD) of the B. thuringiensis growth curve was measured at $600 \mathrm{~nm}$ using a spectrophotometer (Shimadzu, UV-1800). After the decline phase of $B$. thuringiensis growth, the culture was removed and centrifuged at $6000 \mathrm{rpm}$ for 30 minutes. The supernatant was filtered using a sterile $0.22 \mu \mathrm{m}$ filter (Mater et al., 2009). The extract was then centrifuged for 10 minutes at 1000 rpm and $20^{\circ} \mathrm{C}$. The deposit was dissolved in a solution 

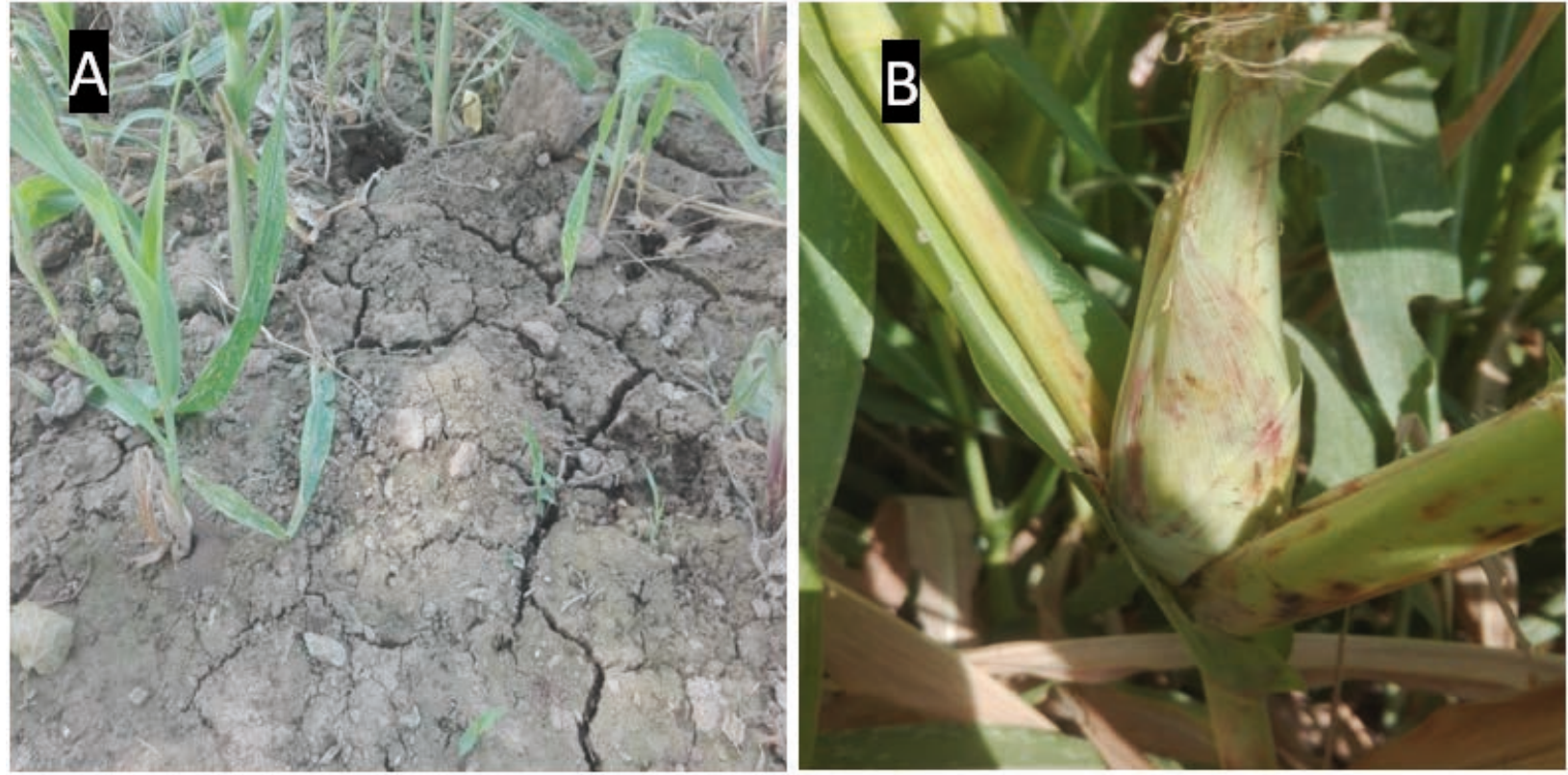

Figure 1: (A) Sampling site of maize rhizospheric soil for the isolation of B. thuringiensis, (B) Diseased maize for the isolation of $F$. graminearum

of methanol (Analytical grade, VWR Chemicals $\mathrm{BDH}^{\circ}$ ) and water $(50: 50, \mathrm{v} / \mathrm{v})$ and filtered again using a $0.22 \mu \mathrm{m}$ filter membrane. For purification, the sample was treated three times with $20 \mathrm{ml}$ chloroform (VWR Chemicals $\mathrm{BDH}^{\circ}$ ). The bottom layer was collected and chloroform was evaporated at $50^{\circ} \mathrm{C}$ temperature by using a hotplate stirrer. Methanol was used to dissolve the residue. Surfactin from the extract were identified by introducing 50 $\mu \mathrm{l}$ of the extract into a Shimadzu 20A UV-Vis HPLC at a wavelength range of $200-250 \mathrm{~nm}$. The isocratic HPLC method was employed, along with a $4.6 \times 150 \mathrm{~mm} \mathrm{C}-18$ normal phase column (Mater et al., 2009). For the identification of surfactin by HPLC experiment, acetonitrile was utilized as a mobile phase. Surfactin were discovered after comparing the observed peak to previously published data (Meena et al., 2014).

\subsection{ANTIFUNGAL ACTIVITY OF LIPOPEPTIDE EXTRACT}

To test the antifungal activity of surfactin, four 5 $\mathrm{mm}$ wells were created on potato dextrose agar (PDA) $\left(\mathrm{Oxoid}^{\mathrm{Tm}}\right)$ using a sterilized cork borer. The methanol was used as a control and also used to create concentrations of the lipopeptide extract of $20 \%, 40 \%, 60 \%$, and $80 \%$, respectively. The wells were filled with $200 \mu \mathrm{l}$ of methanol (control), $20 \%, 40 \%, 60 \%$, and $80 \%$ concentrations of lipopeptide extract, respectively. A colony of active growing F. graminearum was placed in the middle of media plates using sterile forceps and incubated at $30^{\circ} \mathrm{C}$ for 3-7 days. Five repetitive antifungal analysis of the extracted lipopeptde was done by the same method described above. The inhibitory zones were measured and recorded (Mater et al., 2009). The obtained mean zone of inhibitions was analyzed using a one-way ANOVA test using the Statistical Packages for Social Sciences (SPSS) version 23.0 software and Microsoft Excel.

\section{RESULTS AND DISCUSSION}

\subsection{BACTERIAL ISOLATE}

In 20 rhizospheric soil samples $B$. thuringiensis 12 isolates were confirmed by various criteria such as, colony morphology, gram staining, and biochemical assays (Table 1). Previous results revealed that Bacillus species are primarily found in rhizospheric soil and that their metabolites have antibiotic characteristics as they can inhibit or restrict the development of other microorganisms (Amin et al., 2015).

\subsection{FUNGAL ISOLATE}

In context to this study, F. graminearum was isolated from infected maize plants and identified using colony morphology (white to pinkish), and microscopic assessment (Hyaline septate hyphae, two to multi-celled and 
Table 1: Morphological and Biochemical characteristics of $B$. thuringiensis

\begin{tabular}{ll} 
Tests & Results \\
\hline Colony Morphology & $\begin{array}{l}\text { Circular, rough, opaque, fuzzy } \\
\text { white or slightly yellow }\end{array}$ \\
Gram Staining & $\begin{array}{l}\text { Gram Positive } \\
\text { Rhape }\end{array}$ \\
Motility & Positive \\
Catalase & Positive \\
Indole production & Negative \\
Citrate utilization & Positive \\
H2S production & Negative \\
Crystals formation & Positive \\
Identified Strains & B. thuringiensis \\
\hline
\end{tabular}

sickle-shaped) in the current investigation. Fusarium head blight (FHB) disease is caused by F. graminearum in maize. This fungus exhibit certain sign of early bleaching during infection which could reduce grain production and quality (Ntushelo et al., 2019).

\subsection{LIPOPEPTIDE IDENTIFICATION}

According to the current study findings, $B$. thuringiensis was grown to produce lipopeptides, and the optical density (OD) of the growth curve was measured (Figure 2). Lipopeptides isolated from $B$. thuringiensis were analyzed by HPLC using acetonitrile as the mobile phase. At $210 \mathrm{~nm}$ and retention period 3-5 minutes, the observed peak area was 3.990 (Figure 3), which is similar to the peaks found earlier in surfactin literature data (Mubarak et al., 2015). Previous studies are in agreement with our findings. According to the Deepak and Jayapradha

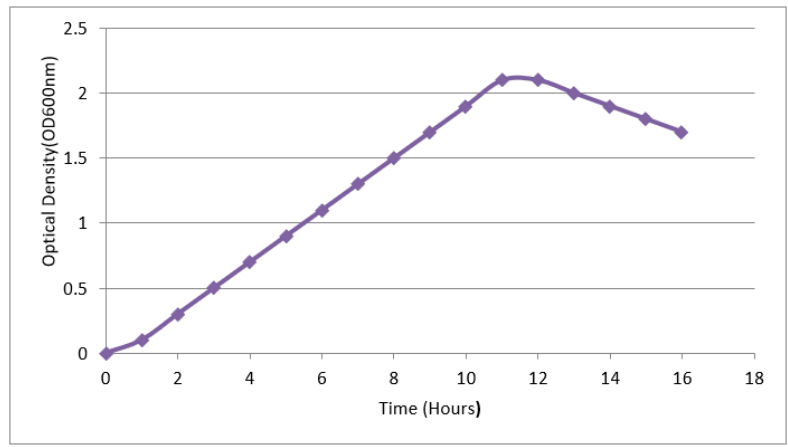

Figure 2: Optical density (OD) of the growth curve of $B$. thuringiensis at $600 \mathrm{~nm}$ wavelength
(2015), they identified lipopeptide surfactin by HPLC which are produced by $B$. thuringiensis. In another study, the lipopeptde fengycin produced by $B$. thuringiensis was identified by HPLC techniques (Kim et al., 2004).

\subsection{ANTIFUNGAL ACTIVITY OF LIPOPEPTIDE}

B. thuringiensis lipopeptide surfactin against the development of $F$. graminearum was investigated in this work. The surfactin lipopeptide efficiently suppressed the growth of $F$. graminearum (Figure 4). According to earlier research, isolated Bacillus spp. from the rhizosphere, particularly $B$. subtilis, reduced the growth of $F$. graminearum. Bacillus spp. is also effective in the prevention of Fusarium head blight (FHB) and root rot; they stimulate plant development and inhibit the mycelial growth of fungal infections through antagonistic action (Herba et al., 2020; Madhi et al., 2020; Dukare et al., 2020). In this study, lipopeptide surfactin from $B$. thuringiensis was tested against F. graminearum at $20 \%, 40 \%, 60 \%$, and $80 \%$ concentrations (Figure 4). The zone of inhibition was the greatest at the $80 \%$ concentration, followed by the $60 \%, 40 \%$, and $20 \%$ concentrations $(p<0.005)$, respectively. These findings are in agreement with previous report, in which the surfactin action against $F$. oxysporum (Deepak and Jayapradha, 2015) was screened. According to a recent study, microorganisms were isolated from plant anthers and wheat kernels to test their antagonistic activity against $F$. graminearum, the causative agent of Fusarium head blight (FHB). B. subtilis has a strong antifungal impact on $F$. graminearum mycelium, sporulation, and DON formation, with inhibition values of $87.9 \%, 95.6 \%$, and $100 \%$, respectively (Zhao et al., 2014).

\section{CONCLUSION}

Lipopeptides obtained from Bacillus species have less negative environmental effects as compared to chemical compounds. The current study concluded that B. thuringiensis isolated from the rhizosphere of maize crop may produce lipopeptide surfactin, which has a high potential to inhibit the growth of F. graminearum. The study is also emphasizing surfactin as potential biological control agent with widespread usage. We are also encouraging other researchers to take advantage of newly invented techniques to explore mechanism of action of various Bacillus strains against phytopathogens. 


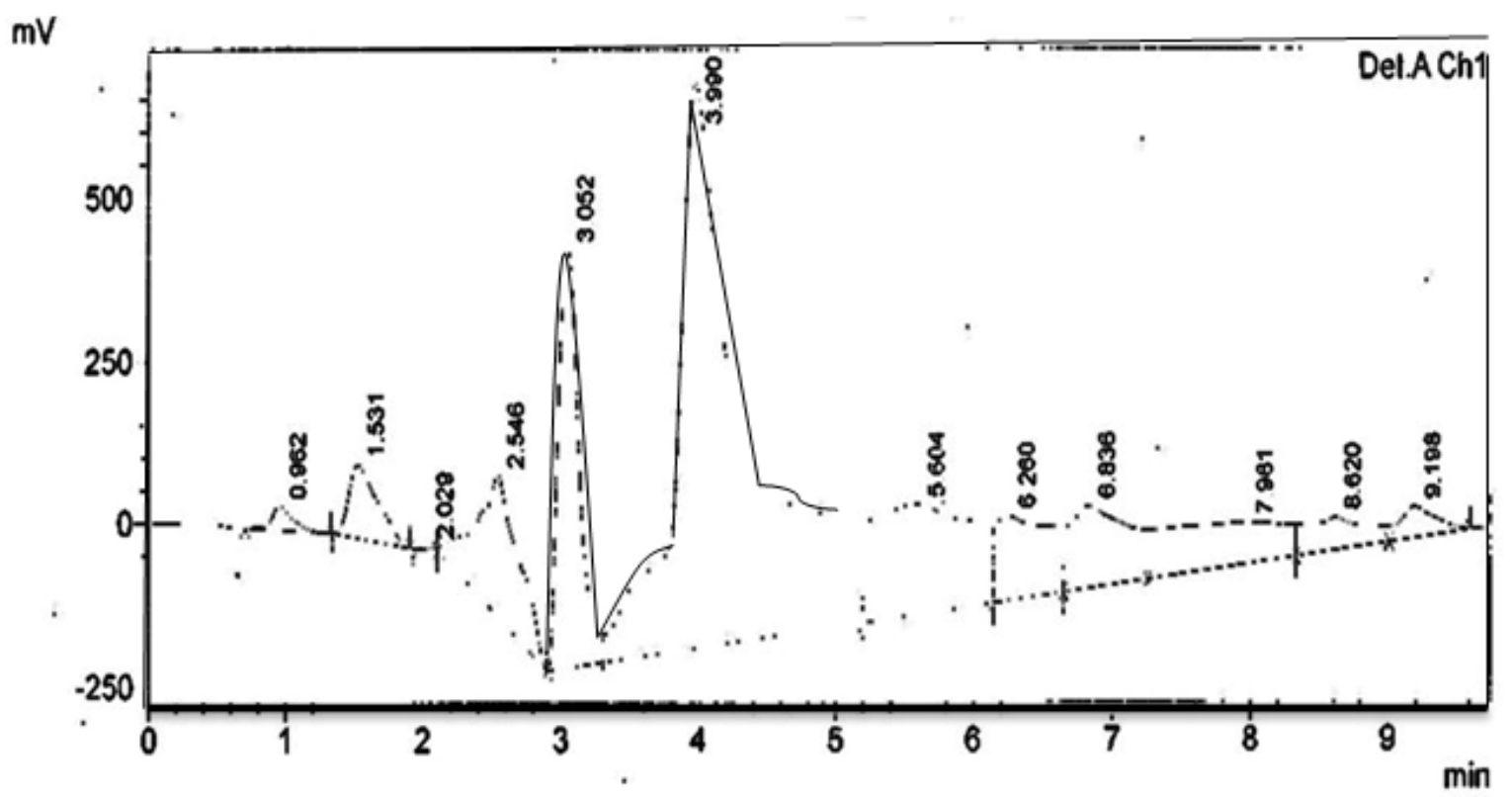

Figure 3: HPLC Chromatogram of $B$. thuringiensis lipopeptide surfactin obtained at 210nm, retention time between 3-5 minutes and peak area 3.990

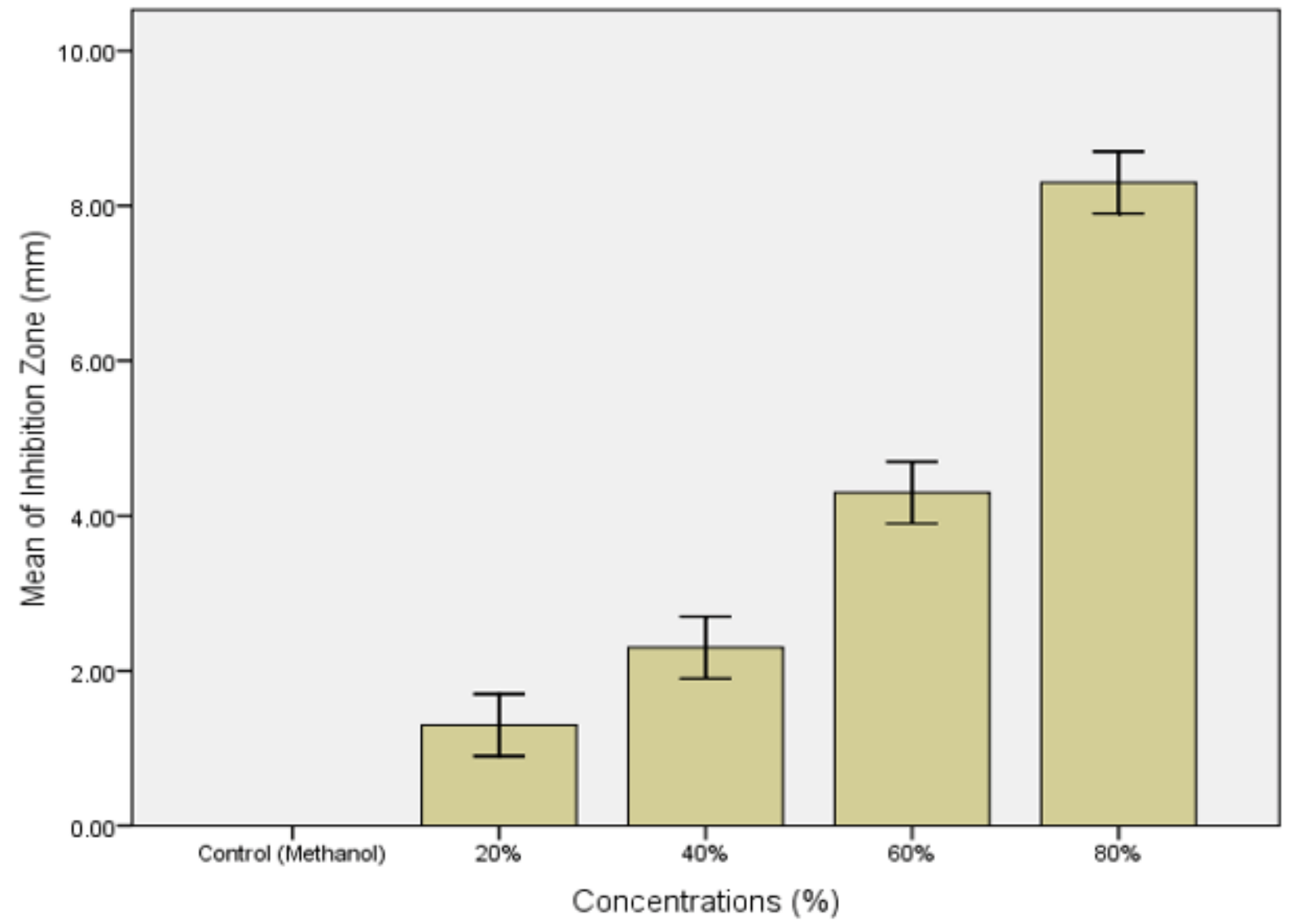

Figure 4: B. thuringiensis lipopeptide surfactin zone of inhibition (mean) against F. graminearum at various concentrations $(p<$ 0.005) 


\section{REFERENCE}

Amin, M., Rakhisi Z., Ahmady A. Z. (2015). Isolation and identification of Bacillus Species from soil and evaluation of their antibacterial properties. Avicenna Journal of Clinical Microbiology and Infection, 2(1), e2323. https://doi. org/10.17795/ajcmi-23233

Deepak, R., Jayapradha, R. (2015). Lipopeptide biosurfactant from Bacillus thuringiensis pak 2310: a potential antagonist against Fusarium oxysporum. Journal de Mycologie Medicale, 25(1), e15-e24. https://doi.org/10.1016/j.mycmed.2014.10.011

Dukare, A., Paul, S., Arambam, A. (2020). Isolation and efficacy of native chitinolytic rhizobacteria for biocontrol activities against fusarium wilt and plant growth promotion in pigeon pea (Cajanus cajan L.). Egyptian Journal of Biological Pest Control, 30, 56. https://doi.org/10.1186/s41938-02000256-7

Dunlap, C. A., Schisler, D. A., Price, N. P., Vaughn, S. F. (2011). Cyclic lipopeptide profile of three Bacillus subtilis strains; antagonists of Fusarium head blight. Journal of Microbiology, 49, 603-609. https://doi.org/10.1007/s12275-0111044-y

Hue, N., Serani, L., Laprevote, O. (2001). Structural investigation of cyclic peptidolipids from Bacillus subtilis by high energy tandem mass spectrometry. Rapid Communication. Mass Spectrometry, 15, 203-209. https://doi.org/10.1002/10970231(20010215)15:3<203::AID-RCM212>3.0.CO;2-6

Hussain, N., Hussain, A., Ishtiaq, M., Azam, S., Hussain, T. (2013). Pathogenicity of two seed-borne fungi commonly involved in maize seeds of eight districts of Azad Jammu and Kashmir, Pakistan. African Journal of Biotechnology, 12(12), 1363-1370.

John, F. L., Brett, A. S. (2016). The Fusarium laboratory manual, First edition, Blackwell Publishing, 2016.

Kant, P., Reinprecht, Y., Martin, C. J., Islam, R., Pauls, K. P. (2011). Disease resistance / Pathology / Fusarium. Elsevier, 00263-4. https://doi.org/10.1016/B978-0-08-0885049.00263-4

Khan, M., Salman, M., Jan, S. A., Shinwari, Z. K. (2021). Biological control of fungal phytopathogens: A comprehensive review based on Bacillus species. MOJ Biology Medicine, 6(2), 90-92. https://doi.org/10.15406/mojbm.2021.06.00137

Kim, P. I., Bai, H., Bai, D., Chae, H., Chung, S., Kim, Y., et al. (2004). Purification and characterization of a lipopeptide produced by Bacillus thuringiensis CMB26. Journal of applied microbiology, 97(5), 942-949. https://doi.org/10.1111/ j.1365-2672.2004.02356.x

Kim, P. I., Ryu, J., Kim, Y. H., Chi, Y. T. (2010). Production of biosurfactant lipopeptides iturin A, fengycin and surfactin from Bacillus subtilis CMB32 for control of Colletotrichum gloeosporides. Journal of Microbiology and Biotechnology, 20, 138-145. https://doi.org/10.4014/jmb.0905.05007

Kwon, S., Rupp, O., Brachmann, A., Blum, C. F., Kraege, A., Goesmann, A., Feldbrügge, M. (2021). mRNA inventory of extracellular vesicles from Ustilago maydis. Journal of Fungi, 7(7), 562. https://doi.org/10.3390/jof7070562

Madhi, Q. H., Jumaah, A. M. (2020). Affectivity evaluation of Bacillus subtilis in controlling eggplant root rot caused by
Rhizoctonia solani and Fusarium solani. IOP Conference Series: Earth and Environmental Science, 553, 012026. https:// doi.org/10.1088/1755-1315/553/1/012026

Mater, S. M., El-Kazzaz, S. A., Waigh, E. E., El-Diwany, A. I., Moustafa, H. E., Abo-Zaid, G. A., Elsalam, A. H. E., Hafez, E. E. (2009). Antagonistic and inhibitory effect of Bacillus subtilis against certain plant pathogenic fungi. Biotechnology, 8(1), 53-61. https://doi.org/10.3923/biotech.2009.53.61

Meena, K. R., Saha, D., Kumar, R. (2019). Isolation and partial characterization of iturin like lipopeptides (a bio-control agent) from a Bacillus subtilis strain. International Journal of Current Microbiology and Applied Sciences, 3(10), 121126.

Mubarak, M. Q. E., Hassan, A. R., Hamid, A. A., Khalil, S., Isa, M. H. M. (2015). A simple and effective isocratic HPLC method for fast identification and quantification of surfactin. Sains Malaysiana. https://doi.org/10.17576/jsm-20154401-16

Ntushelo, K., Ledwaba, L. K., Rauwane, M. E., Adebo, O. A., Njobeh, P. B. (2019). The mode of action of Bacillus species against Fusarium graminearum, tools for investigation and future prospects. Toxins, 11, 606. https://doi.org/10.3390/ toxins 11100606

Pal, K. K., Gardener, B. M. (2006). Biological control of plant pathogens. The Plant Health Instructor, 1-25. https://doi. org/10.1094/PHI-A-2006-1117-02

Rauwane, M. E., Ogugua, U. V., Kalu, C. M., Ledwaba, L. K., Woldesemayat, A. A., Ntushelo, K. (2020). Pathogenicity and virulence factors of Fusarium graminearum including factors discovered using next generation sequencing technologies and proteomics. Microorganisms, 8(2), 305. https://doi.org/10.3390/microorganisms8020305

Rehman, F., Adnan, M., Kalsoom, M., Naz, N., Husnain, M. G., Ilahi, H., Ilyas, M. A., Yousaf, G., Tahir, R., Ahmad, U. (2021). Seed-borne fungal diseases of maize (Zea mays L.): A review. Agrinula: Jurnal Agroteknologi Dan Perkebunan, 4(1), 43-60. https://doi.org/10.36490/agri.v4i1.123

Ren, J., Li, Z., Wu, P., Zhang, A., Liu, Y., Hu, G., et al. (2021). Genetic dissection of quantitative resistance to common rust (Puccinia sorghi) in tropical maize (Zea mays L.) by combined genome-wide association study, linkage mapping, and genomic prediction. Frontiers in plant science, 12, 1338. https://doi.org/10.3389/fpls.2021.692205

Saleem, M. J., Bajwa, R., Hannan, A., Qaiser, T. A. (2012). Maize seed storage mycoflora in Pakistan and its chemical control. Pakistan Journal of Botany, 44(2), 807-812.

Saxena, A. K., Kumar, M., Chakdar, H., Anuroopa, N., Bagyaraj, D. J. (2020). Bacillus species in soil as a natural resource for plant health and nutrition. Journal of Applied Microbiology, 128(6), 1583-1594. https://doi.org/10.1111/jam.14506

Shafi, J., Tian, H., Ji, M. (2017). Bacillus species as versatile weapons for plant pathogens: a review. Biotechnology \& Biotechnological Equipment, 31(3), 446-459. https://doi.or $\mathrm{g} / 10.1080 / 13102818.2017 .1286950$

Snetselaar, K., McCann, M. (2017). Ustilago maydis, the corn smut fungus, has an unusual diploid mitotic stage. Mycologia, 109(1), 140-152. https://doi.org/10.1080/00275514.2 016.1274597

Snook, M. E., Mitchell, T., Hinton, D. M., Bacon, C. W. (2009). 
Isolation and characterization of Leu7-surfactin from the endophytic bacterium Bacillus mojavensis RRC 101, a biocontrol agent for Fusarium verticillioides, Journal of Agriculture and Food Chemistry, 57, 4287-4292. https://doi. org/10.1021/jf900164h

Uddin, M. N., Nasrullah, Khan, M. (2019). Isolation and Identification of fungal pathogens associated with diseases of onion crop in district Swat, Pakistan. Abasyn Journal of Life Sciences, 2(2), 91-99.

Vitullo, D., Di Pietro, A., Romano, A., Lanzotti, V., Lima, G.
(2012). Role of new bacterial surfactins in the antifungal interaction between Bacillus amyloliquefaciens and Fusarium oxysporum. Plant Pathology, 61, 689-699. https://doi. org/10.1111/j.1365-3059.2011.02561.x

Zhao, Y., Selvaraj, J. N., Xing, F., Zhou, L., Wang, Y., Song, H., Tan, X., Sun, L., Sangare, L., Folly, Y. M. E. (2014). Antagonistic action of Bacillus subtilis strain SG6 on Fusarium graminearum. PLoS ONE, 9, e92486. https://doi. org/10.1371/journal.pone.0092486 